\title{
Inese Stepina
}

\section{Produktivitāte:}

\section{kāpēc būtiska Latvijai un Latvijas uzṇēmējiem?}

Publiskajā diskusijā pēdējā laikā aizvien lielāku ievērību guvusi produktivitātes (latviešu valodā - ražìguma) tēma. Lai gan sarunu par to ir daudz, padziḷināta izpratne vēl ir nepieciešama.

Latvijā par produktivitāti valda mīti, lai gan vairākus gadus kompetentas iestādes un eksperti ir publiskojuši pētijumus, viedokḷu rakstus, prognozes un atziṇas par nepieciešamajiem soḷiem produktivitātes kāpināšanā.

Populārākais joprojām ir mīts: lai paaugstinātu produktivitāti, kādam ir jāsāk strādāt ātrāk un ilgāk. Šāda produktivitātes izpratne ir l̦oti vienkāršota. Lai būtu produktīvāks, tieši otrādi - ir jāstrādā mazāk, bet ar daudz efektīvākiem līdzekḷiem sasniedzot labāku rezultātu. Otrs populārākais mīts ir priekšstats, ka produktivitāte ir nepieciešama starptautiskai konkurētspējai. Produktivitātes virsmērḳis nav konkurētspēja, bet gan cilvēks un viņa labklājība.

Valsts iedzīvotāju labklājību mazas un atvērtas ekonomikas lielā mērā var panākt, vairojot savu eksportspēju ar augstus ienākumus nesošu produkciju, un tam ir nepieciešama 
starptautiska konkurētspēja - konkurētspējīgas preces un pakalpojumi - un pircēji, kas gatavi tos iegādāties par augstu samaksu.

Latvijas ekonomikas nepietiekamās produktivitātes sekas diemžēl ir acīmredzamas, jo pēdējās dekādēs Latvijas valsti un uzṇēmumus ir pametis būtisks Latvijas cilvēkkapitāla īpatsvars, aizbraucot uz valstīm, kurās uzņēmumi ir produktīvāki, jo ir konkurētspējīgāki. Cilvēkam ir dabīga tieksme pēc labklājības. Jautājums - kā sasniegt labklājības valsti, kurā ir sekmīgi iedzīvotāji un produktīvi uzñēmumi, un kas ir izšķirošais?

Ir nepieciešams turpināt skaidrot, ko mūsdienās nozīmē produktivitāte. Primāri produktivitāte ir saistāma ar ieguldījumiem cilvēkos. Produktivitāte tiek saistīta arī ar tehnoloǵisko progresu, tomēr tehnoloǵiju pienesums izaugsmei ir lielāks tur, kur ir prasmīgi un īpaši sagatavoti cilvēki, kas gan prot tehnoloğijas izmantot $^{1}$, gan tās radìt un attīstìt.

\section{Kāpēc produktivitāte?}

Kā norāda Pasaules Bankas grupas analīze, iekšzemes kopprodukta (turpmāk tekstā - IKP) uz vienu iedzìvotāju atškịiības starp dažādām valstīm lielākajā daḷā izskaidrojamas ar produktivitātes atšķirīibām. Produktivitātes pieaugums, proti, efektivitāte, ar kādu sabiedrība apvieno savus cilvēkus, resursus un citus rīcībā esošos ražošanas faktorus, ir attīstības galvenais virzītājspēks. ${ }^{2}$ Šìs atziṇas nav jaunas.

Pazīstamais ekonomists Pauls Krugmans (Paul Krugman) jau pagājušā gadsimta 90. gadu sākumā pauda pārliecību, ka vienīgais veids, kā panākt ilgstošu dzīves līmeņa pieaugumu, ir palielināt produktivitāti. ${ }^{3}$ Arī šìs atziṇas nav jaunas - tās atbalso viduslaiku arābu sociālā teorētiķa Ibn Khaldun (1332-1406) pārdomas izdevumā Muqaddimah (1377): civilizācija un tās labklājība, kā arī uzṇēmējdarbības labklājība ir atkarīga no produktivitātes. ${ }^{4}$

\footnotetext{
1 Rinaldi G. 2017. Economics for Social Negotiators. International Training Centre of the International Labour Organisation, Turin, Italy, p. 41.

2 Cusolito A. P. and Maloney W. F. 2018. Productivity Revisited. Shifting Paradigms in Analysis and Policy. International Bank for Reconstruction and Development, The World Bank, p. xi. Revieved from https://openknowledge.worldbank.org/bitstream/handle/10986/30588/9781464813344.pdf?Sequence= 9\&isallowed=y [viewed 25.03.2019]; OECD Compendium of Productivity Indicators 2018. OECD, Publishing Paris, p. 3. Revieved from https://read.oecd-ilibrary.org/economics/oecd-compendium-of-productivity-indicators-2018_pdtvy-2018-en\#page1 [viewed 25.03.2019].

3 P. Krugmans nepieciešamību palielināt produktivitāti (ražīgumu) primāri nesaista ar nepieciešamību spēt nodrošināt starptautisko konkurētspēju, bet ar dzīves līmeṇa pieaugumu (Krugman P. 1997. Chapter 1, Productivity growth. In: The Age of Diminished Expectations. U.S. Economic Policy in the 1990s. 3rd ed., The MIT Press, Cambridge, Massachusetts, London, England, pp. 11, 12).

4 Cusolito A. P. and Maloney W. F. 2018, p.xi.
} 
Pasaules ekonomikas forums ${ }^{5}$ konkurētspēju definē kā institūciju, rīcībpolitiku un faktoru kopumu, kas nosaka valsts produktivitātes līmeni. ${ }^{6}$ Produktivitāte tiek uzskatīta par ekonomikas izaugsmes un konkurētspējas galveno avotu. ${ }^{7}$ Savukārt produktivitātes līmenis nosaka labklājības līmeni, ko var sasniegt noteiktas valsts ekonomika. Produktivitātes līmenis nosaka arī peḷnas līmeni, ko iegūst, investējot ekonomikā, proti, lielākai produktivitātei ir augstāka investīciju atdeve. Investīcijas savukārt ir ekonomikas izaugsmes tempu galvenais virzìtājspēks. Produktīvāka un līdz ar to konkurētspējīgāka ekonomika būs tā, kas laika gaitā attīstīsies straujāk. ${ }^{8}$

Pēdējās dekādēs darba produktivitātes pieaugums ir palēninājies visā pasaulē. ${ }^{9}$ Turklāt nodarbinātība ir pieaugusi tieši sektoros un jomās ar relatīvi zemāku darba produktivitāti, pasliktinot kopējos darba produktivitātes rādītājus; tendence atspoguḷo nodarbinātības pieaugumu nozarēs, kuras visvairāk skāra finanšu un ekonomiskā krīze. Vairāk darba vietu zemāka darba ražīguma aktivitātēs nozīmē arī vairāk darba vietu ar zemākām algām lielākajā daļā ekonomikas. ${ }^{10}$

Attīstīto valstu produktivitāte, kas ir sekmējusi šo valstu labklājību, ir samazinājusies un vienlaikus arī draud samazināt tempus, kādos notiek visu pasaules valstu izaugsme un kādos tiek samazināta nabadzība pasaulē. Produktivitātes pieaugums samazinās, neraugoties uz iespaidīgiem sasniegumiem skaitḷošanas jomā un ar to saistītajām tehnologijāàm; solījums par strauju progresu, izmantojot zinātni un tehnolog̣ijas, šķiet, tomēr neiet roku rokā ar novēroto lēnāko produktivitātes pieaugumu pasaulē. Bažas rada tas, ka atpalicības darba produktivitātē jaunattīstības un attīstības valstīs rada būtisku šķērsli konvergenencei ar attīstìto valstu ekonomikas ienākumu līmeni. Daudzām valstīm draud noturīga atpalicība. ${ }^{11}$

5 Angḷu valodā The World Economic Forum, starptautiska publiskās un privātās sadarbības organizācija. Dibināta 1971. gadā kā bezpeḷnas fonds, atrodas Ženēvā, Šveicē. Forums iesaista politiskos, uzṇēmējdarbības un citus sabiedrības līderus, veidojot globālas, regionālas un rūpniecības diskusiju dienaskārtību. Forums tiecas parādìt uzṇēmējdarbību pasaules sabiedrības interesēs, vienlaikus ievērojot visaugstākos pārvaldības standartus. Izgūts no https://www.weforum.org/about/world-economic-forum [skatīts 26.03.2019.].

6 World Economic Forum. 2014. The Global Competitiveness Report 2014-2015: Full Data Edition. World Economic Forum - The Global Competiotiveness and Benchmarking Network, Geneva $(\mathrm{CH})$, p. 4. Revieved from http://www3.weforum.org/docs/WEF_globalcompetitivenessreport_2014-15.pdf [viewed 26.03.2019]; Insight Report. The Global Competitiveness Report 2018, p. 43. Revieved from http://www3.weforum.org/docs/GCR2018/05fullreport/theglobalcompetitivenessreport2018.pdf [viewed 26.03.2019].

7 OECD Compendium of Productivity Indicators 2018, p. 9.

$8 \quad$ World Economic Forum. 2014, p. 4.

9 Cusolito A. P. and Maloney W. F. 2018, p. xi.

10 OECD Compendium of Productivity Indicators 2018, p. 3.

11 Cusolito A. P. and Maloney W. F. 2018, pp. xi, xvii, xvii. 


\section{Atvērtas ekonomikas un tirdzniecības loma produktivitātē}

Ekonomiskās sadarbības un attīstības organizācija (turpmāk tekstā $\mathrm{OECD}^{12}$ ) akcentē, ka teorētiski vairāk atvērtās ekonomikās ir lielāka izaugsme un augstāks ienākumu līmenis nekā mazāk atvērtās ekonomikās. Starptautiskā tirdzniecība rada iespēju uzṇēmumiem specializēties tās produkcijas radīšanā, kuru radīt konkrētajā valstī ir visefektīvāk, pārdot saražoto lielākos tirgos, iegūstot no apjoma, ko sniedz pieeja pasaules tirgiem, kā arī gūt labumu no augstākas kvalitātes un ieguldījumu dažādības, tehnologiskās ietekmes un zināšanu apmaiņas. Tirdzniecỉba arī rada spiedienu uz galaproduktu un starppatēriņa cenām, veicina ražošanas procesu starptautisko specializāciju, vēl vairāk samazinot izmaksas. ${ }^{13}$

Atvērtākas ekonomikas ir inovatīvākas, un to tirgi konkurētspējīgāki. ${ }^{14}$ Tas gan ir iespējams, ja uzñēmumi, kas pakḷauti starptautiskai konkurencei, nepārtraukti ievieš jauninājumus, lai gūtu panākumus. ${ }^{15}$ Tieši veids, kā uzṇēmumi ražo, ietekmē to produktivitāti un attiecīgi arī izmaksas. Vienīgi produktīvi uzņēmumi var augt, radìt pel̦nu un maksāt labu atalgojumu. ${ }^{16}$

Rìcíbpolitikas veidotāji pasaulē ir centušies izskaidrot produktivitātes krituma cēloṇus globāli, kaut gan nav vienas un skaidras atbildes uz šo fenomenu. ${ }^{17}$ Šã iemesla dēl arī produktivitāte kā tēma ir ieguvusi no jauna ievērību politiskajā diskursā. Joprojām ir aktuāli noteikt rīcībpolitikas virzienus, lai veicinātu produktivitāti, samazinot nabadzību un izpildot iedzīvotāju pieaugošās vēlmes. ${ }^{18}$

Mazām un atvērtām ekonomikām eksports veido lielāko daļu no iekšzemes kopprodukta. ${ }^{19}$ Tāpēc Latvijai, lai uzlabotu valsts un tās iedzīvotāju labklājību, spēja starptautiski konkurēt ar augstas pievienotās vērtības produkciju ir būtiska. Aktuāls ir jautājums, kā celt uzñēmumu produktivitāti, lai uzlabotu konkurētspēju reǵionā, Eiropā un pasaulē, lai spētu pārdot produkciju ar augstu pievienoto vērtību un spētu maksāt labu atalgojumu darbiniekiem un uzlabotu Latvijas iedzīvotāju dzìves līmeni.

\footnotetext{
12 Angḷu val. Organisation of Economic Development and Cooperation (OECD), dibināta 1961. gadā kā starpvalstu organizācija, šobrīd apvieno 36 pasaules attīstītākās valstis, no tām 23 ES dalībvalsts, to skaitā Latviju. OECD misija ir veicināt rīcībpolitiku, kas uzlabo cilvēku ekonomisko un sociālo labklājỉbu visā pasaulē. Izgūts no http://www.oecd.org/about/; https://www.mfa.gov.lv/arpolitika/ekonomiskas-attiecibas/ekonomiskas-sadarbibas-un-attistibas-organizacija-oecd/oecd [skatìts 27.03.2019.].

13 OECD Compendium of Productivity Indicators 2018, p. 76.

14 Insight Report. The Global Competitiveness Report 2018, p. ix.

15 OECD Compendium of Productivity Indicators 2018, p. 76.

16 Rinaldi G. 2017, p. 26.

17 World Economic Forum. 2016. Global Agenda. Inclusive Growth Framework. What is productivity, and how do you measure it?, 12 July 2016, Petra Jachan. Revieved from https://www.weforum.org/ agenda/2016/07/what-is-productivity-and-how-do-you-measure-it/ [viewed 26.03.2019].

18 Cusolito A. P. and Maloney W. F. 2018, pp. xi, xvii.

19 Rinaldi G. 2017, p. 245.
} 
Latvijai ir potenciāls, bet tas nav pietiekami izmantots. Pirms nākt klajā ar produktivitātes celšanas rīcībpolitiku, jāturpina skaidrot, kas ir produktivitāte, kas to veido un kā to var mērìt.

\section{Kas ir produktivitāte, un kā to mērīt?}

Produktivitāti parasti definē, kā attiecību starp rezultāta (angḷu val. output) apjomu iepretim resursu (angḷ val. input) apjomam. Produktivitāte raksturo to, cik efektīvi tiek izmantoti resursi, proti, cik efektīvi ekonomikā, lai iegūtu noteiktu ražošanas apjomu, tiek izmantoti ražošanas resursi - darbaspēks un kapitāls. ${ }^{20}$ Tā kā produktivitātes virsmērḳis ir radīt labklājību, būtiski ir ne tikai vienkārši radīt vairāk rezultātu ar mazākiem resursiem, bet - radīt vērtīgāku rezultātu, proti, spēt transformēt nelielus ražošanas faktoru daudzumus lielā daudzumā vērtīgas produkcijas. ${ }^{21}$

Lai gan pastāv vienprātība attiecībā uz produktivitātes vispārējo definīciju jeb izpratni, produktivitātes analīze ir atkarīga no mērḳa, kādiem nolūkiem tā tiek veikta. Attiecīgi arī produktivitātes mērauklas var būt atšķirīgas. ${ }^{22}$ Kopumā produktivitātes mērījumus var klasificēt kā viena faktora produktivitātes mērvienības vai visu ražošanas faktoru kombināciju mērvienības ${ }^{23}$, balstoties vai nu uz bruto izlaides, vai pievienotās vērtības rezultātu efektivitātes novērtējumu attiecībā pret vienu vai vairākiem ieguldītajiem resursiem. ${ }^{24}$

Biežāk izmantotais produktivitātes mērījums, arī Latvijā, ir viena faktora - darba produktivitātes (angḷu val. labour productivity) - mērījums pēc nostrādāto stundu skaita vai strādājošo skaita iepretim saražotajai vērtībai. ${ }^{25}$ Tomēr, ņemot vērā ražošanas procesā ieguldìtā kapitāla (angḷu val. capital input) nozīmi, būtiski ir analizēt, kāda ir kapitāla produktivitāte (angḷu val. productivity of capital), proti, atdeve uz vienu ieguldito naudas vienību iepretim saražotajai produkcijai. ${ }^{26}$

20 ILO home, Productivity. Revieved from https://www.ilo.org/global/topics/dw4sd/themes/productivity/lang--en/index.htm [viewed 25.03.2019]; ILO. 16: Labour Productivity. International Labour Organization - Key Indicators of the Labour Market. 9th ed., International Labour Office, Geneva, 2015, p. 131. Revieved from https://www.ilo.org/global/topics/dw4sd/themes/productivity/lang--en/index. htm [viewed 25.03.2019]; OECD Compendium of Productivity Indicators 2018, p. 9.

$21 \quad$ Rinaldi G. 2017, p. 32.

22 Measuring Productivity. 2001. Measurement of Agregate and Industry-level Productivity Growth. OECD Manual, OECD, p. 11. Revieved from http://www.oecd.org/sdd/productivity-stats/2352458.pdf [viewed 25.03.2019].

23 Ibid, p. 12.

$24 \quad$ ILO home, Productivity; ILO. 16: Labour Productivity, p. 131.

25 OECD Compendium of Productivity Indicators 2018, p. 9.

26 Rinaldi G. 2017, p. 32; OECD Compendium of Productivity Indicators 2018, p. 9. 
1. tabula. Galvenie produktivitātes faktori un mērījumi

\begin{tabular}{|c|c|c|c|c|}
\hline \multirow[b]{2}{*}{$\begin{array}{l}\text { Rezultāta } \\
\text { (output) } \\
\text { mērījums }\end{array}$} & \multicolumn{4}{|c|}{ leguldīto resursu (input) mērïjuma veids } \\
\hline & Darbs & Kapitāls & Kapitāls un darbs & $\begin{array}{c}\text { Kapitāls, darbs un } \\
\text { starppatēriṇa resursi } \\
\text { (anglu val. - intermediate } \\
\text { inputs (energija, materiāli, } \\
\text { pakalpojumi)) }\end{array}$ \\
\hline $\begin{array}{l}\text { Bruto } \\
\text { izlaide }\end{array}$ & $\begin{array}{l}\text { Darba } \\
\text { produktivitāte } \\
\text { (balstīta uz } \\
\text { bruto izlaidi) }\end{array}$ & $\begin{array}{l}\text { Kapitāla } \\
\text { produktivitāte } \\
\text { (balstīta uz } \\
\text { bruto izlaidi) }\end{array}$ & $\begin{array}{c}\text { Kapitāla-darba } \\
\text { daudzfaktoru } \\
\text { produktivitāte (balstīta } \\
\text { uz bruto izlaidi) }\end{array}$ & $\begin{array}{c}\text { Kapitāla-darba- } \\
\text { starppatēriña resursu } \\
\text { (anglu val. KLEMS) } \\
\text { daudzfaktoru produktivitāte }\end{array}$ \\
\hline \multirow[t]{2}{*}{$\begin{array}{l}\text { Pievienotā } \\
\text { vērtība }\end{array}$} & $\begin{array}{c}\text { Darba } \\
\text { produktivitāte } \\
\text { (balstīta uz } \\
\text { pievienoto vērtību) }\end{array}$ & $\begin{array}{c}\text { Kapitāla } \\
\text { produktivitāte } \\
\text { (balstīta uz } \\
\text { pievienoto vērtību }\end{array}$ & $\begin{array}{c}\text { Kapitāla-darba } \\
\text { daudzfaktoru } \\
\text { produktivitāte (balstīta } \\
\text { uz pievienoto vērtību) }\end{array}$ & - \\
\hline & \multicolumn{2}{|c|}{ Viena faktora produktivitātes mērījums } & \multicolumn{2}{|c|}{ Daudzfaktoru produktivitātes (DFP) mērījums ${ }^{27}$} \\
\hline
\end{tabular}

Avots: Measuring Productivity, p. 13. Autores tulkojums no anglu valodas

Apvienojot darba un kapitāla ieguldījumu analīzi, tiek iegūts daudzfaktoru produktivitātes (anglu val. multifactor productivity) mērïjums ${ }^{28}$, kas atspogulo darbaspēka un kapitāla kombinētā izmantojuma efektivitāti ražošanas procesā, vienlaikus novērtējot arī citus faktorus, ko nevar izskaidrot tikai ar darbaspēka un kapitāla ieguldījuma izmain̦ām. ${ }^{29}$

Darba produktivitāte palielinās, ja pievienotā vērtība palielinās, pateicoties visu ražošanas faktoru labākai izmantošanai, koordinācijai utt. Pievienotā vērtība var pieaugt, ja darbaspēks strādā gudrāk, grūtāk, ātrāk vai ar labākām prasmēm. Pievienotā vērtība var arī palielināties, izmantojot vairāk vai labākas iekārtas, samazinot izejmateriālu izšķērdēšanu vai ieviešot tehnolog̣iskus jauninājumus. ${ }^{30}$

Darba produktivitāte ir atkarīga no darbinieku centieniem, tā ir atkarīga arī no darba organizācijas, no aprīkojuma veida un daudzuma, ko darbinieki izmanto, no uzṇēmuma veiktajiem ieguldījumiem, uzņēmuma uzṇēmējdarbības stratēgijas pamatotîbas, piemēram, augstas vērtības vai zemas vērtības produktu ražošana, un daudziem citiem faktoriem, kas ne vienmēr ir darbinieku kontrolē. Recesijas laikā produktivitāte bieži krītas ne vienmēr tāpēc, ka strādnieki nav ar mieru strādāt, bet gan tāpēc, ka uzñēmumi nav spējīgi pārdot. ${ }^{31}$

\footnotetext{
27 Arī t. s. kopējā faktoru produktivitāte (angḷu val. total factor productivity) (Rinaldi G. 2017, p. 36).

28 Citos izdevumos minēts arī kā kopējā faktoru produktivitāte (angḷu val. total factor productivity) (Rinaldi G. 2017, p. 36).

29 OECD Compendium of Productivity Indicators 2018, p. 10; Rinaldi G. 2017, p. 36.

30 ILO home, Productivity; ILO. 16: Labour Productivity, p. 131.

$31 \quad$ Rinaldi G. 2017, p. 40.
} 
Tāpat darba produktivitāte ir atkarīga no ražošanas procesā izmantotā tehnologiju veida (anglu val. rigid or flexible production techniques). Dažas tehnologiijas izmanto vairāk darbaspēku un mazāk kapitālu, piemēram, roku darbs, lauksaimniecība attīstības valstīs - tā sauktās darbietilpīgās tehnologijas (angḷu val. labour intensive technologies). Pretēji citas tehnologijas ir saistìtas ar kapitāla lielāku izmantošanu un mazāku darbaspēka izmantošanu, piemēram, jomās ar augstu automatizācijas līmeni, naftas ražošanā, telekomunikācijas, dzelzceḷa un gaisa pārvadājumu jomā - tā sauktās kapitālietilpīgās tehnologijas (angḷu val. capital-intensive technologies). Konkrētos gadījumos resursu kopums, ko uzn̄ēmumi izvēlas, var arī nespēt aizstāt viens otru, proti, cilvēku nevar aizstāt tehnika, vienu speciālistu nevaru aizvietot cits speciālists, vienu tehniku nevar aizvietot cita tehnika vai cilvēks. ${ }^{32}$

\section{Uzņēmumi un produktivitāte: izaicinājumi un risinājumi}

Darba organizācija ir ekonomikas un uzṇēmējdarbības attīstìbas pamatā, un tai ir būtiska ietekme uz produktivitāti, jauninājumiem un darba apstākḷiem..$^{33}$ Uzṇēmumi ir galvenie pievienotās vērtības rādītāji un izaugsmes virzītājspēks. ${ }^{34}$

Tieši veids, kā uzṇēmumi ražo, ietekmē to produktivitāti un attiecīgi arī to izmaksas. ${ }^{35}$ Papildus efektivitātes mērījumiem uzṇēmuma darbības rezultāti vai rentabilitāte ir atkarīgi no plašākas uzņēmumu attīstības virzības, proti, produktu kvalitātes un produktu pieprasijuma pieauguma. Kvalitātes paaugstināšana var faktiski samazināt efektivitāti, jo, lai nodrošinātu augstāku kvalitāti, ir nepieciešams vairāk darba vai dārgāku resursu, bet galarezultātā šāda pieeja palielina produktu diferenciāciju un kopējo peḷnu. ${ }^{36}$

Vienīgi produktīvi uzṇēmumi var augt, radìt peḷnu un maksāt labas algas. ${ }^{37}$ Zema produktivitāte ir viens no strādājošo nabadzības iemesliem, proti, cilvēki strādā ilgstošas stundas, bieži vien neformālajā ekonomikā jeb ēnu ekonomikā, vai gūst ienākumus mazproduktīvās nozarēs, bet joprojām nesaṇem pietiekami daudz, lai varētu uzturēt savas ǵimenes. ${ }^{38}$

$32 \quad$ Rinaldi G. 2017, pp. 26, 27.

33 Work organisation. 2017. Eurofound, European Observatory of Working Life, 24 July 2017. Revieved from https://www.eurofound.europa.eu/observatories/eurwork/about-eurwork/work-organisation [viewed 26.03.2019].

34 Cusolito A. P. and Maloney W. F. 2018, p. xxiv.

35 Rinaldi G. 2017, p. 26

36 Cusolito A. P. and Maloney W. F. 2018, p. xxiv.

37 Rinaldi G. 2017, p. 26.

38 ILO home, Productivity. 
Produktīvai izaugsmei labvēlīgais attīstỉbas virziens nosaka to, ka produktivitāte, nodarbinātîba un attīstîba var tikt sekmēta, produktivitātes pieauguma ietekmē gūto peḷnu ieguldot produktu un procesu inovācijās, iekārtās un to modernizācijā, pasākumos, lai uzlabotu darbaspēka prasmes un uzlabotu darba vidi. ${ }^{39}$

Starptautiskā Darba organizācija (turpmāk tekstā - SDO) ${ }^{40}$ ìpaši akcentē, ka produktivitātes pieaugumam var būt ietekme uz nodarbinātîbu un tas var pat izraisìt daudzu nodarbinātības veidu izzušanu. Jaunās tehnologiijas un darba procesu automatizācija var radīt un jau rada nopietnas izmaiṇas darba tirgū, un šìs sekas ir diskusiju centrā par darba jeb nodarbinātības nākotni (angḷu val. future of work). Pieredze tomēr rāda, ka ilgtermiņā un kopumā produktivitātes pieaugums ne vienmēr var samazināt nodarbinātības pieaugumu valstī. Darba vietu zudumu vienā jomā vai nozarē kompensē darba vietu pieaugums citā jomā vai nozarē. Produktivitātes pieaugums, ja tiek panākts ar mehanizāciju un fosilā kurināmā izmantošanu, var arī negatīvi ietekmēt vidi un veicināt klimata pārmaiņas. Tāpēc vēlamākā ir darba vietu radīšana, kas samazina iespējamās negatīvās sekas. ${ }^{41}$

SDO atbalsta produktivitātes pieaugumu, izmantojot prasmju pilnveidošanas programmas, nostiprinot darba tirgus institūcijas, izveidojot sociālā dialoga mehānismus un izmantojot īpašus projektus un programmas, kas orientētas uz atbalstu konkurētspējīgiem un atbildīgiem uzņēmumiem, darba apstākḷu un konkurētspējas uzlabošanu rūpniecības nozarēs, veicinot produktivitātes paaugstināšanu, uzlabojot darba organizāciju un apjomradītus (angḷu val. economies of scale) ietaupījumus dažādās nozarēs, veicinot lielāku resursu efektivitāti un ekonomiku ar zemu oglekḷa emisiju līmeni. ${ }^{42}$

\section{Galvenie produktivitātes indikatori Latvijā}

Eiropas Komisija (turpmāk tekstā - EK) savā gadskārtējā ziṇojumā par Latviju 2019. gadā norāda, ka kopumā produktivitāte starp Latvijas reǵioniem

39 ILO home, Productivity; World Economic Forum. Global Agenda. Inclusive Growth Framework. What is productivity, and how do you measure it?, 12 July 2016, Petra Jachan. Revieved from https://www. weforum.org/agenda/2016/07/what-is-productivity-and-how-do-you-measure-it/ [viewed 26.03.2019].

40 Angḷu val. International Labour Organisation, dibināta 1919. gadā un ir vienīgā Apvienoto Nāciju Organizācijas (ANO) aǵentūra, kas apvieno 187 dalībvalstu valdības, darba devēju un darba ņēmēju pārstāvjus, lai noteiktu darba standartus, izstrādātu rīcībpolitiku un programmas, kas veicina cienīgus nodarbinātības nosacījumus. SDO akcentē, ka sociālais taisnīgums ir būtisks vispārējam un ilgstošam mieram. Izgūts no https://www.ilo.org/global/about-the-ilo/mission-and-objectives/lang--en/index. htm [skatīts 25.03.2019.].

${ }_{41} \quad$ ILO home, Productivity.

42 Turpat. 
būtiski atškiriras. Rīgas reǵionā tā sasniedz 74\% no ES vidējā rādītāja, bet citos regionos produktivitāte ir daudz zemāka, piemēram, Latgalē tā ir tikai $38 \%{ }^{43}$

Kvalificēta darbaspēka un labu darba iespēju trūkums ietekmē attālo reǵionu konkurētspēju un ir viens no galvenajiem emigrācijas cēloṇiem. ${ }^{44}$ Nabadzības riska rādītājs ir augstāks lauku apvidos un krietni pārsniedz ES vidējo rādītāju. ${ }^{45}$ Iespēju nevienlīdzība turpina pastāvēt attiecībā uz piekḷuvi izglìtībai un veselības aprūpei. Digitālās prasmes ir zemākas par ES vidējo rādītāju: pusei iedzīvotāju (52\%) trūkst digitālo pamatprasmju, vēl izteiktāka atškirīiba ir padziḷinātu prasmju jomā. ${ }^{46}$

Uzṇēmumus Latvijā raksturo inovācijas perspektīvu trūkums, mazs izmērs, zema pievienotā vērtība, augsta resursu intensitāte un integrācijas trūkums globālajās vērtību ķēdēs. Lielākā daḷa ražotāju (65\%) darbojas nozarēs, kurās tehnolog̣ijas tiek izmantotas maz, piemēram, koksnes un metāla pamatapstrādē, un kurās ir mazas inovācijas izredzes. Tikai $2 \%$ ražošanas uzņēmumu darbojas augsto tehnologiiju nozarēs. Reǵionos uzṇēmumi izjūt arī finansējuma un pakalpojumu pieejamības trūkumu, aktīvā darbaspēka vispārējo prasmju neatbilstîbu pieprasījumam ražošanas nozarēs. Šie faktori nesekmē ārējās investīcijas, kas ir nepieciešamas, lai veicinātu reğionu ekonomisko attīstỉbu. ${ }^{47}$

Latvijas ekonomikas relatīvi zemā konkurētspēja, salīdzinot ar vairāk attīstītajām un turīgākajām ES valstīm, kā arī Latvijas atvērtā ekonomika atspoguḷojas augstajā Latvijas iedzīvotāju emigrācijas līmenī. Valstīm, uz kurām aizcel̦ojuši Latvijas iedzīvotāji, izmantojot ES personu kustības brīvību darba iespēju izmantošanas nolūkos, ir būtiski augstāks konkurētspējas vērtējums nekā Latvijai ${ }^{48}$ un būtiski augstāka pozīcija daudzos produktivitātes rādītājos.

EK īpaši analizē produktivitāti no darbaspēka vienību izmaksu un darba produktivitātes perspektīvas. Tomēr, lai gan EK rīcībā ir dati par kopējo faktoru produktivitāti Latvijā ${ }^{49}$, analīze šajā jautājumā netiek izvērsta, proti, netiek vērtēts darba un kapitāla ieguldījums kopējā produktivitātē.

43 Komisijas dienestu darba dokuments. 2019. gada ziņojums par Latviju. Pavaddokuments Komisijas paziņojumam Eiropas Parlamentam, Eiropadomei, Padomei, Eiropas Centrālajai Bankai un Eirogrupai 2019. gada Eiropas pusgadā - novērtējums par progresu strukturālo reformu īstenošanā, makroekonomikas nelīdzsvarotības novēršanā un korig̣ēšanā, un saskaņā ar Regulu (ES) Nr. 1176/2011 veikto padziḷināto pārskatu rezultāti, SWD/2019/1013 final, Briselē, 27.02.2019., SWD (2019) 1013 final, 51., 52. lpp.

44 Turpat, 51., 52. 1pp.

45 Turpat, 11. lpp.

46 Turpat, 39. lpp.

47 Turpat, 51., 52. lpp.

48 Stepiņa I. 2014. Konkurētspēja: Latvijas un Eiropas darba devēju skatījums. Latvijas intereses Eiropas Savienībā, 2014/4. Rīga: Dardedzes hologrāfija, 39., 40. lpp. Izgūts no http://www.es2015.lv/images/ es_2014_4.pdf [skatìts 12.03.2019.].

49 Komisijas dienestu darba dokuments. 2019. gada ziņojums par Latviju, 14. 1pp. 
2. tabula. Ar produktivitāti saistīto atsevišḳo indikatoru salīdzinājums

\begin{tabular}{|c|c|c|c|c|c|c|c|}
\hline Indikators & Latvija & Lietuva & Igaunija & $\begin{array}{l}\text { Liel- } \\
\text { britānija }\end{array}$ & Īrija & Vācija & Norvēgijija \\
\hline $\begin{array}{l}\text { Konkurētspējas } \\
\text { novērtējums (vieta, GCR }{ }^{a} \text { ) }\end{array}$ & 42 & 40 & 32 & 8 & 23 & 3 & 16 \\
\hline $\begin{array}{l}\text { Spēja atrast kvalificētus } \\
\text { darbiniekus (vieta, GCR }{ }^{b} \text { ) }\end{array}$ & 97 & 123 & 112 & 8 & 12 & 7 & 5 \\
\hline $\begin{array}{l}\text { Universitāšu un } \\
\text { industrijas sadarbība } \\
\text { pētniecībā (reitings, GIIc) }\end{array}$ & 93 & 36 & 39 & 6 & 13 & 7 & 19 \\
\hline $\begin{array}{l}\text { IKT pieejamība } \\
\left.\text { (reitings, GII }{ }^{d}\right)\end{array}$ & 40 & 52 & 19 & 4 & 21 & 6 & 24 \\
\hline $\begin{array}{l}\text { Augsto tehnologiju } \\
\text { ražošana, \% (reitings, GII })\end{array}$ & 82 & 58 & 56 & 20 & 3 & 5 & 49 \\
\hline $\begin{array}{l}\text { Stundas darba } \\
\text { produktivitāte (Eurostat, } \\
\% \text { no ES vidējāj) }\end{array}$ & $58,3 \%$ & $66,6 \%$ & $65,4 \%$ & $97,9 \%$ & $176 \%$ & $127,5 \%$ & $146,9 \%$ \\
\hline $\begin{array}{l}\text { Samaksa un } \\
\text { produktivitāte } \\
\text { (vieta, GCR })\end{array}$ & 46 & 40 & 21 & 14 & 12 & 6 & 35 \\
\hline
\end{tabular}

a,b The Global Competitiveness Report 2018, Schwab K. (ed.), World Economic Forum Editor, The World Economic Forum, 2018. Revieved from http://www3.weforum.org/docs/GCR2018/05FullReport/TheGlobalCompetitivenessReport2018.pdf.

c Global Innovation Index (GII) 2018. 5.2.1. University/industry research collaboration.

Revieved from https://www.globalinnovationindex.org/analysis-indicator.

d Ibid., 3.1.1. ICT Access.

Ibid., 6.2.5. High-tech and medium-high-tech output.

Eurostat [nama_10_lp_ulc].

g The Global Competitiveness Report 2018.

Avots: autores veidota tabula, izmantojot starptautiski salīdzināmus indikatorus

OECD savā produktivitātei ìpaši veltītajā 2018. gada izdevumā atsevišķi pievēršas daudzfaktoru produktivitātes - darba un kapitāla produktivitātes kopējā devuma - analīzei. Tiesa, šo analīzi OECD izvērš vienīgi uz noteiktu valstu grupu $^{50}$, par kurām dati ir pieejami lielākoties kopš 1985. gada. ${ }^{51}$ Daudzas valstis, tostarp Latvija, netiek analizētas, jo par šìm valstīm OECD statistikas datubāzē nav pieejami dati par kapitāla produktivitāti un attiecīgi arī par daudzfaktoru produktivitāti. Arī ES statistikā par daudzām ES valstīm, arī par Latviju,

50 Austrālija, Austrija, Beḷgija, Kanāda, Dānija, Somija, Francija, Vācija, Grieḳija, İrija, Itālija, Japāna, Koreja, Luksemburga, Nīderlande, Jaunzēlande, Norvēǵija, Portugāle, Spānija, Zviedrija, Šveice, Apvienotā Karaliste un Amerikas Savienotās Valstis.

51 OECD Compendium of Productivity Indicators 2018, pp. 19, 20, 46, 47; Growth in GDP per capita, Productivity and ULC: capital productivity. Revieved from https://stats.oecd.org/index. aspx?datasetcode=pdb_lv, skatits: 26.03.2019; Growth in GDP per capita, Productivity and ULC: multifactor productivity. Revieved from https://stats.oecd.org/index.aspx?datasetcode=pdb_lv [viewed 26.03.2019]. 
ir nepilnīga dažādu nozaru kapitāla resursu uzskaite, un attiecīgi nav iespējams pilnvērtīgi veikt kapitāla ietekmes uz produktivitāti analīzi. ${ }^{52}$

Informācijas trūkums par kapitāla kā resursa ietekmi uz produktivitāti nelauj mums pilnvērtīgi spriest par investīciju Latvijā faktisko kvalitāti un investīciju ietekmi uz Latvijas ekonomikas kopumā un dažādo uzṇēmējdarbības sektoru produktivitāti un konkurētspēju, proti, vai un cik lielā mērā Latvijā ieguldìtais tiek pārvērsts augstas pievienotās vērtības produkcijā, kuru pārdodam pasaulē, uzlabojam ārējās tirdzniecības bilanci un spējam nopelnīt, lai veiktu produktīvus ieguldījumus un uzlabotu konkurētspēju.

\section{Rekomendācijas pārejai uz augstas pievienotās vērtības ekonomiku}

Konkurētspēju veido institūciju, rīcībpolitiku un faktoru kopums, kas nosaka valsts produktivitātes līmeni. ${ }^{53}$ Rīcībpolitikai ir jābūt vērstai uz to, lai uzlabotu gan uzṇēmējdarbības vidi, gan cilvēkkapitālu un uzṇēmumu spējas..$^{54}$ Latvijai izšḳirīgas būtu šādas darbības.

- Strikti ievērot ES sniegtās brīvības un pasaules starptautiskās tirdzniecỉbas kārtỉbu.

Daudzi Latvijas iedzīvotāji iepriekšējos gados dažādu iemeslu dēl ir aizbraukuši no Latvijas. ES sniegtās brīivibas l̦oti daudziem ir devušas starptautisku darba, uzṇēmējdarbības vai studiju pieredzi ES valstīs. Latvijas iedzīvotājiem ir būtiski atgriezties Latvijā, dalīties ar iegūto pieredzi, veidot šo valsti un sabiedrību labāku, strādāt savas labklājības labā Latvijā. Savukārt Latvijas uzṇēmumiem ir būtiski turpināt attīstìt savu eksportspēju uz valstīm ar augstāku maksātspēju un ar augstas pievienotās vērtības produkciju paaugstināt savas pozīcijas globālajās piegādes ķēdēs. ${ }^{55}$

\section{- Uzturēt tiesiskumu, kas ir produktīvas uzņēmējdarbības pamats.}

Tiesiskums, adekvāta institucionālā un ekonomiskā rīcībpolitika ir nepieciešama videi, kas sekmē cilvēku palikšanu, atgriešanos, piesaista prasmīgus darba ṇēmējus no citām valstīm, sekmīgu un drošu uzṇēmējdarbību, piesaista

52 EU KLEMS, The Conference Board. 2017. Trusted Insights for Business Worldwide. EU KLEMS Growth and Productivity Account. 2017 Release, Statistical Module, Description of methodology and country notes for the Czech Republic. Prepared by Kirsten Jäger (The Conference Board), p. 4. Revieved from http://www.euklems.net/TCB/2017/CZ_documentation_2017.pdf [viewed 27.03.2019].

53 World Economic Forum. 2014, p. 4; Insight Report. The Global Competitiveness Report 2018, p. 43.

54 Cusolito A. P. and Maloney W. F. 2018, p. xxii.

55 LDDK stratēgija 2014.-2020. gadam. Darba izpilde par 2018. gadu un darba plāns 2019. gadam, 54. lpp. Apstiprināts LDDK biedru sapulcē 2019. gada 29. martā, protokols Nr. 1. Izgūts no http://www.lddk. lv/wp-content/uploads/2019/04/20190329_lddkstrategija2014-2020_darbaplans_2019_final_web.pdf [skatits 01.04.2019.]. 
ilgtspējīgas ienākošā un vietējā kapitāla investīcijas un veido pamatu inovācijām un attīstībai. Nepieciešams sekmēt starptautiskajiem standartiem atbilstošas risku pārvaldības ieviešanu uzṇēmumos un uzraugošajās iestādēs, tostarp istenot neiecietīgu attieksmi pret ekonomiskajiem noziegumiem un prettiesiskām darbībām. ${ }^{56}$

\section{- Nodrošināt produktìvas investīcijas un attīstìt cilvēkkapitālu.}

Latvijas izaicinājums ir vēlme un spēja piesaistìt produktīvas investīcijas, lai palielinātu darbaspēka līdzdalību darba tirgū, sekmētu uzṇēmējdarbību un produktivitāti. Jāiegulda cilvēkkapitālā (veselībā, izglīīīā, prasmēs), nepieciešams balanss ar ieguldỉjumiem infrastruktūrā, neproduktīvām investīcijām ${ }^{57}$, piemēram, ar nekustamajiem īpašumiem un citiem ar patēriṇu saistītiem ieguldỉjumiem. Latvijas Centrālajai statistikas pārvaldei sadarbībā ar Eiropas un starptautiskajiem statistikas dienestiem, piemēram, Eurostat un OECD.stat, un uzņēmumiem Latvijā būtu jāuzsāk kapitāla produktivitātes uzskaite un analīze par ieguldỉjumu kopējā produktivitātē.

Lai praktiski spētu nodrošināt darba produktivitātes pieaugumu un konkurētspējīgu atalgojumu, veicinātu augstas pievienotās vērtỉbas tehnoloǵiju radīšanu un komercializēšanu, sekmētu videi draudzīgu tehnolog̣iju un uzñēmējdarbības attīstību, Latvijas Darba devēju konfederācija (LDDK) $)^{58}$ ir apṇēmusies sekmēt šādas prioritāras darbības ${ }^{59}$ :

- ražošanas resursu izmaksu konkurētspēju un ilgtspējīgu izmantošanu un attīstību

Tas nozīmē pieejamo ražošanas resursu (dabas, kapitāla, darba, uzṇēmējspēju), enerğijas avotu un izejvielu (elektrība, gāze, koksne) un infrastruktūras (transporta, sakaru, tirdzniecības, energèetikas, ūdenssaimniecības, dzīvokḷu, skolu, veselības aizsardzības, kultūras, sporta u. tml.) efektīvu un ilgtspējīgu izmantošanu un attīstību, izvērtējot un sabalansējot klimata mērḳu ietekmi uz tautsaimniecību, attīstot ilgtspējīgu uzn̦ēmējdarbību un radot labvēlīgus nosacījumus investīcijām augstākas pievienotās vērtības nozarēs; ${ }^{60}$

\footnotetext{
56 LDDK stratēgija 2014.-2020. gadam, 14. lpp.

$57 \quad$ Rinaldi G. 2017, pp. 106, 109, 217.

58 LDDK ir lielākā un ietekmīgākā darba devējus pārstāvošā organizācija Latvijā. LDDK misija: veidot Latvijas uzṇēmējdarbību atbalstošu vidi, veicinot uzṇēmēju konkurētspēju un pārstāvot darba devējus sociālā dialoga ietvaros nacionālā, ES un starptautiskā līmenī. Izgūts no http://www.lddk.lv/lapa/par$1 \mathrm{ddk} /$ [skatīts 17.03.2019.].

59 LDDK stratēgija 2014.-2020. gadam.

60 Turpat, 4. lpp.
} 
- priekšnoteikumus Latvijas uzṇēmumu produktivitātes pieaugumam

Tas nozīmē veicināt darbaspēka un kapitāla pārdali no mazāk produktīviem uz augstāk produktīviem uzṇēmumiem un nozarēm, uzṇēmumu sadarbību ar augstskolām un citu valstu uzṇēmumiem, kā arī starpdisciplināru sadarbību dažādu inovatīvu produktu radīšanā un komercializācijā. ${ }^{61}$ Tas nozīmē arī izvērtēt nodokḷu politikas ietekmi uz darba devēju konkurētspēju un spēju piesaistīt kvalificētu darbaspēku, ieviestās $0 \%$ uzṇēmumu ienākuma nodokḷa likmes reinvestētajai pel̦nai ietekmi uz uzñēmumu ieguldỉjumiem izpētē un attīstībā. Tas nozīmē arī veicināt darba tirgū nepieciešamo speciālistu - informācijas un komunikācijas tehnologiju speciālistu, augsti kvalificētu speciālistu ķīmijas, farmācijas, elektronikas, kokrūpniecības un citās nozarēs ar informācijas un komunikācijas tehnolog̣iju prasmēm ${ }^{62}$ - pieejamību, sekmēt jauniešu izvēli par labu izglītỉbai dabaszinātṇu, matemātikas un inženierzinātṇu (STEM) jomās ${ }^{63}$, darba tirgus pārmaiṇu vadību un nepieciešamo prasmju apguvi digitalizācijas, automatizācijas un tehnolog̣iju ietekmē..$^{64}$

${ }_{61}$ LDDK stratēgija 2014.-2020. gadam, 54. lpp.

62 Turpat, 58. lpp.

63 Turpat, 54. lpp.

64 Turpat, 14., 58. lpp. 